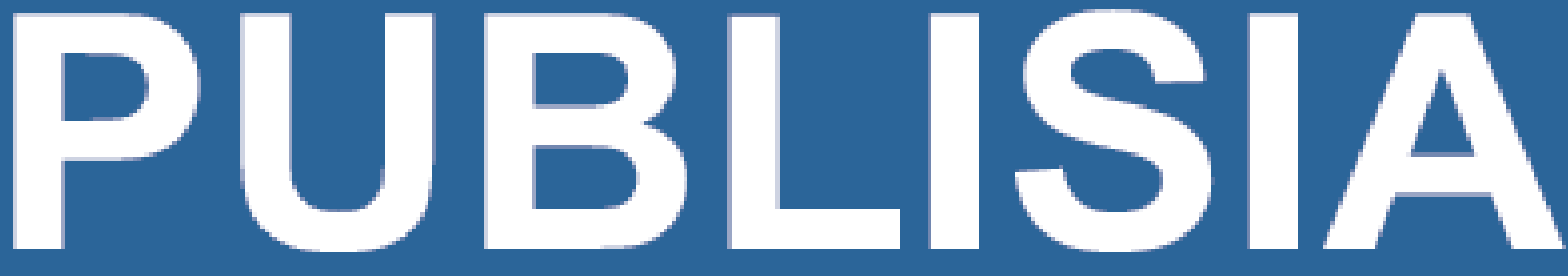

\title{
Jurnal Ilmu Administrasi Publik
}

Buruh anak: mamp ukah kebijakan negara melind ungi?

FajarAprani

Pembinaan Anak Jalanan Melalui Home Shelter "Griya Baca" Kota Malang Sebagai Upaya Menuju Kota Layak Anak

Erfinandus G. Sebawan

Calur Wahyudi

Sn Hartini Jatnikowali

Remunerasi dan Problem Reformasi Birokrasi Di Indonesia

Happy Susanio
Implamentasi Undang - Undang No mor 23 Tahun 2002 Tontang Porilindungan A nak Dalam Rangka Mowujdukan Kota Madang Sobagd Kota Layak Anak (Studl pada Dinas Soslal Pamerintah Kota Matangl

Dpo Pratoma

Tighonulin Dongl Ryanto

Penerapan New Public Management (NPM) DI Indonesia (Reformasi Birokrasi, Desentralisasi, Kerjasama Pemerintah dan Swasta Dalam Meningkatkan Pelayanan Publik)

AniAgus Puspawati

Studi Etnografi Perilaku Pengemis Masyarakat Desa Pragaan Daya Kabupaten Sumenep

Rina Hardyantina

Sukardi

Media Difusi Efektif untuk Sosialisasi Kebijakan Akselerasi Pengembangan PasarTradisional MenujuSemi Modern

Saldah

\section{PROGRAM STUDI ADMINISTRASI PUBLIK FAKULTAS ILMU SOSIAL DAN ILMU POLITIK UNIVERSITAS MERDEKA MALANG}




\title{
P U B L I S I A \\ JURNAL ILMU ADMINISTRASI PUBLIK \\ Diterbitkan Oleh \\ Program Studi Administrasi Publik \\ Fakultas IImu Sosial dan IImu Politik \\ Universitas Merdeka Malang
}

PUBLISIA (Jurnal IImu Administrasi Publik) merupakan terbitan berkala ilmiah yang diterbitkan Oleh Program Studi Administrasi Publik - FISIP Universitas Merdeka Malang. Memuat berbagai hasil kajian teoritik dan hasil penelitian di bidang Administrasi Publik dengan tujuan untuk membangun kolaborasi antar komunitas epistemik di bidang Administrasi Publik.

Awal berdirinya, ditahun 1997 jurnal ini bernama "Publisia: Jurnal Kebijakan Publik" terbit sebanyak 4 kali dalam setahun, kemudian ditahun 2004 mendapatkan ISSN (p) 1410-0983 dengan judul terbitan "Publisia: Jurnal Sosial dan Politik". Ditahun 2014, terbitan berkala ini berganti judul dengan "PUBLISIA (Jurnal IImu

Administrasi Publik) yang terbit secara cetak. Ditahun 2016 terbit dalam 2 versi (Cetak dan Online), perubahan sub judul pada terbitan berkala ini diajukan pembaruan sehingga ISSN (p): 2541-2515, di versi

online ISSN (e): 2541-2035. Setiap tahun terbit sebanyak 2 kali, di Bulan April dan Oktober.

Link Jurnal Online: http://jurnal.unmer.ac.id/index.php/jkpp

\author{
Ketua Penyunting \\ Chandra Dinata \\ Wakil Ketua Penyunting \\ Umi Chayatin \\ Penyunting Pelaksana \\ Budhy Priyanto \\ Catur Wahyudi \\ Praptining Sukowati \\ Dwi Suharnoko \\ Penyunting Ahli \\ Sukardi (Universitas Merdeka Malang) \\ Purwo Santoso (Universitas Gadjah Mada) \\ Bambang Supriono (FIA Universitas Brawijaya Malang) \\ Mas'ud Said (Universitas Muhammadiyah Malang) \\ Agus Solahuddin, MS. (Universitas Merdeka Malang) \\ Yopi Gani (Perguruan Tinggi IImu Kepolisian) \\ Kridawati Sadhana (Universitas Merdeka Malang) \\ Sujarwoto (FIA Universitas Brawijaya Malang) \\ Tri Yumarni (Universitas Jenderal Soedirman) \\ Mitra Bestari \\ Mudjianto (Universitas Negeri Malang)
}

Alamat Penyunting \& Tata Usaha: Gedung Fakultas Ilmu Sosial dan Politik (FISIP)

Unversitas Merdeka Malang, Jl. Terusan Raya Dieng 62-64 Malang 65145,

Telp. (0341) 580537, e-mail: publisia.jopad@unmer.ac.id 


\section{P U B L I S I A \\ JURNAL ILMU ADMINISTRASI PUBLIK \\ PROGRAM STUDI ADMINISTRASI PUBLIK - FAKULTAS ILMU SOSIAL DAN POLITIK \\ UNIVERSITAS MERDEKA MALANG}

\section{VOLUME 01, NOMOR 01, APRIL 2016}

\section{DAFTAR ISI}

Fajar Apriani Buruh anak: mampukah kebijakan negara melindungi?

Dipa Pratama Implementasi Undang - Undang Nomor 23

Tjahjanulin Domai Tahun 2002 Tentang Perlindungan Anak Dalam

Riyanto Rangka Mewujdukan Kota Malang Sebagai Kota Layak Anak (Studi pada Dinas Sosial

Pemerintah Kota Malang)

Erfinandus G. Setiawan

Catur Wahyudi

Sri Hartini Jatmikowati

Ani Agus Puspawati

Happy Susanto

Remunerasi dan Problem Reformasi Birokrasi

Di Indonesia

Rina Hardiyantina

Sukardi

Saudah
$54-69$

Pembinaan Anak Jalanan Melalui Home Shelter "Griya Baca" Kota Malang Sebagai Upaya Menuju Kota Layak Anak

Studi Etnografi Perilaku Pengemis Masyarakat Desa Pragaan Daya Kabupaten Sumenep $70-91$

Media Difusi Efektif untuk Sosialisasi Kebijakan Akselerasi Pengembangan Pasar Tradisional Menuju Semi Modern 


\title{
PEMBINAAN ANAK JALANAN MELALUI HOME SHELTER "GRIYA BACA" KOTA MALANG SEBAGAI UPAYA MENUJU KOTA LAYAK ANAK
}

\section{ERFINANDUS G. SETIAWAN \\ CATUR WAHYUDI \\ SRI HARTINI JATMIKOWATI} Program Studi Administrsai Publik, Fakultas Ilmu Sosial dan Ilmu Politik,
Universitas Merdeka Malang

\begin{abstract}
Home Shelter "Griya Baca" of the places for training street children and a non-profit organization. The function and purpose of home shelter "Griya Baca" is to accompany and steer of street children to find the identity, and facilitate the process to achieve his goals. Another function that becomes the institutional mission is to reduce the rate of growth of street children in Malang City. The activities of home shelter "Griya Baca" is coaching about spiritual values and morality asbasis capital for changing of behavior patterns without any sense of presure.
\end{abstract}

Key Word : Home Shelter, spiritual values, morality, change of behavior

\section{Intisari}

Home Shelter (rumah singgah) "Griya Baca" merupakan salah satu tempat untuk pembinaan anak jalanan dan merupakan organisasi non-profit. Fungsi dan tujuan rumah singhah "Griya Baca" iniadalah untuk mendampingi dan mengarahkan anak-anak jalanan agar menemukan jati diri serta memfasilitasi proses untuk meraih cita-citanya. Fungsi lain yang menjadi misi kelembagaan adalah untuk menurunkan laju pertumbuhan anak-anak jalanan di Kota Malang. Kegiatan-kegiatan pembinaan dalam rumah singgah "Griya Baca" adalah menanamkan nilai-nilai spiritual dan moral sebagai modal dasar untuk merubah pola laku peserta binaan tanpa ada rasa paksaan.

Kata Kunci: Rumah singgah, nilai spiritual, moralitas, perubahan perilaku.

\section{PENDAHULUAN}

Anak adalah sebagai generasi penerus dan pewaris cita-cita perjuangan bangsa dan merupakan potensi sumber daya manusia (SDM) yang berkualitas, anak mempunyai hak dan kebutuhan untuk hidup yang perlu dipenuhi yaitu: hak dan kebutuhan untuk makan dengan zat-zat yang bergizi, hak untuk mendapat kesehatan, hak untuk bermain, kebutuhan emosional, pengembangan moral, spiritual, pendidikan, serta memerlukan lingkungan keluarga dan sosial dan mendukung kelangsungan hidupnya.
Persoalan yang berkaitan dengan anak-anak jalanan seperti yang terjadi dikota Malang saat ini khususnya di salah satu rumah singgah dimana penulis melakukan observasi yakni di "Griya Baca", disebabkan atau dilatarbelakangi oleh beberapa alasan yang sangat fundamental. Alasan-alasan tersebut dapat dijelaskan sebagai berikut: Anak-anak jalanan memilih hidup dijalanan karena disebabkan oleh factor kondisi kesulitan ekonomi dan faktor dari dalam keluarga ,dimana dalam suatu keluarga sering terjadi pertengkaran sehingga mereka anak 
jalanan juga menikmati kondisi lingkungan dijalanan, anak jalanan tidak selalu tidak memiliki tempat tinggal. Disisilain, anak-anak merasa stress dengan kondisi keluarga dan lingkungan rumahnya terkadang memilih jalanan sebagai lingkungan hidupnya. Dilingkungan hidupnya, anak jalanan melakukan banyak aktifitas seperti yang sudah dikatakan sebelumnya yaitu mengamen, mengemis dan masih banyak aktifitas lainnya.

Melihat kenyataan diatas, sungguh sangat memprihatinkan bagi pencapaian kehidupan masyarakat yang lebih sejahtera. Oleh karena itu, salah satu langkah untuk menanggulangi atau mengatasi persoalan tersebut, peran pemerintah sebagai penanggung jawab sangat dibutuhkan. Penanganan permasalahan anak jalanan jika dimasukkan dalam kebijakan PMKS masih terlalu umum, sehingga kebijakan ini belum mampu memberikan dampak positif bagi anak jalanan itu sendiri, dan pada kenyataanya masih banyak anak jalanan yang belum mendapat perlindungan yang maksimal dari pemerintah daerah setempat sebagai penanggung jawab utama. Sebagai penanggung jawab, pemerintah daerah harus melakukan beberapa upaya yang berkaitan dengan fenomena tersebut. Dibawah ini ada beberapa upaya yang dilakukan pemerintah daerah setempat, yakni Pemerintah Kota Malang merupakan bentuk implikasi dari kebijakan yang diformulasikan dalam rangka mengatasi permasalahan anak jalanan yang multidimensional.

Tahun 2010 Kota Malang ditunjuk sebagai salah satu pengembang Kota Layak Anak (KLA). Salah satu indicator bagi Kota Layak Anak adalah adanya kebijakan mengenai Peraturan Daerah Perlindungan Perempuan dan Anak. Jika Kota Malang sudah ditetapkan menjadi bagian dari pengembangan Kota Layak Anak, maka Kota Malang harus mempunyai Peraturan Daerah yang otonom. Dengan adanya Perda Perlindungan Perempuan dan Anak, maka upaya dan tindakan dalam perlindungan anak jalanan akan lebih fokus, tidak seperti pada Keputusan Walikota Nomor 88 Tahun 2011 yang focusnya masih terpecah dalam 28 kategori PMKS.

Dalam implementasi kebijakan terhadap anak jalanan di kota Malang saat ini telah tersedia sebanyak 7 (tujuh) rumah singgah yang menjadi potensi signifikan untuk mengatasi persoalan anak jalanan. Dari sekian banyak rumah singgah yang telah dibangun atau dikembangkan pemerintah daerah maupun dari Lembaga Swadaya Masyarakat (LSM), salah satu rumah singgah 
yang menjadi tempat penulis melakukan penelitian adalah rumah singgah "Griya Baca". Adapun beberapa fenomena yang terjadi dirumah singgah Griya Baca seperti: Pertama menyangkut tingkat-tingkat kerberhasilan yang diperoleh atau dicapai dari anak-anak tersebut terutama yang berhubungan dengan hal pembinaan mental dan spiritual, baik fisik maupun psikis. Selain hal-hal yang berhubungan dengan tingkat keberhasilan, adapun hal lain yang terjadi seperti variasi dalam arti hal yang berhubungan dengan banyaknya anak-anak jalanan yang berasal dari berbagai wilayah atau daerah yang terbentang diwilayah Nusantara.

Pada bagian yang kedua berkaitan dengan jumlah anak-anak jalanan yang terdapat di rumah singgah "Griya Baca". Dari data-data yang telah dikumpulkan, pada tahun 2014 sampai tahun 2015 ada 75 anak jalanan yang dibina di "Griya Baca". Dari data tersebut, lembaga PAUD (Pendidikan Anak Usia Dini) tidak termasuk dalam proses pendataan. Bahkan lebih dari itu, masih ada banyak anak-anak jalanan yang belum terdata kurang lebih 100 anak. Berkaitan dengan pendataan anak-anak jalanan yang terdapat di "Griya Baca", proses pembinaan dan pembimbingan terhadap anak-anak tersebut diprioritaskan pada golongan usia kurang dari
18 tahun. Usia diatas 18 tahun keatas tidak lagi dilakukan pembinaan tetapi masih dalam pengawasan dan bimbingan serta organisasi atau LSM yang bersangkutan. Pada ketiga, menyangkut kegiatan-kegiatan yang dilakukan oleh anak-anak jalanan di rumah singgah "Griya Baca". Dari proses penelitian yang dilakukan penulis, kegiatan-kegiatan yang dilakukan bermacam-macam seperti penyuluhan, memberikan pembelajaran tentang materi yang ada di sekolah (bimbingan belajar), kegiatan mengaji Iqra' dan Qur'an, belajar tari, dan belajar musik.

Malang sebagai kota pendidikan tak luput dari wilayah persdaran anak-anak jalanan.hampir disetiap perempatan lampu merah atau di depan pertokohan mewah dan dialun-alun kota menjadi tempat yang amat strategis bagi anak jalanan dalam mencari penghidupan. Kehidupan jalanan yang keras tercermin pada tampang sangar, acak-acakan bahkan kumuh yang melekat pada tubuh mereka.pandangan negatif menambah gambaran kelam keberadaan mereka di tengah hiruk pikuk ramainya kota.

Tulisan ini merupakan hasil penelitian yang dilakukan di Kecamatan Klojen Kota Malang dengan tujuan untuk: Pertama, mendeskripsikan dan menganalisis proses manajemen HomeShelter (rumah singgah) "Griya Baca" di Kota Malang; dan kedua, 
mendeskripsikan serta menganalisis berbagai pendukung dan penghambat dalam pelaksanaan tatakelola homeshelter (rumah singgah) "Griya Baca" di Kota Malang.

\section{PEMBINAAN ANAK JALAN SEBAGAI BENTUK KEBERPIHAKAN KEBIJAKAN SOSIAL}

Kebijakan sosialadalah salah satu bentuk dari kebijakan publik. Kebijakan sosial merupakan ketetapan pemerintah yang dibuat untuk merespon isu-isu yang bersifat publik, yakni mengatasi masalah sosial atau memenuhikebutuhan masyarakat banyak. Kebijakan sosial Menurut Suharto, (2008:9) dipahami sebagai kebijakan yang berkaitan dengan kesejahteraan (welfare), baik dalam arti luas, yang menyangkut kualitas hidup manusia, maupun dalam arti sempit, yang menunjuk pada beberapa jenis pemberian pelayanan kolektif tertentu guna melindungi kesejahteraan rakyat.

Sebagai sebuah kebijakan publik, kebijakan sosial memiliki fungsi preventif (pencegahan), kuratif (penyembuhan), dan pengembangan. Kebijakan sosial adalah ketetapan yang didesain secara kolektif untuk mencegah terjadinya masalah sosial (fungsi preventif), mengatasi masalah sosial (fungsi kuratif) dan mempromosikan kesejahteraan (fungsi pengembangan) sebagai wujud kewajiban negara (state obligation)dalam memenuhi hak-hak sosial warganya (Suharto, 2005:13).

Menurut Suharto (2000:10) secara garis besar, kebijakan sosial diwujudkan dalam beberapa kategori yakni perundangundangan, program pelayanan sosial, dan sistem perpajakan, seperti berikut ini :

1. Peraturan dan perundang-undangan: Pemerintah memiliki kewenangan membuat kebijakan publik yang mengatur pengusaha, lembaga pendidikan, perusahaan swasta agar mengadopsi ketetapan-ketetapan yang berdampak langsung pada kesejahteraan.

2. Program pelayanan sosial: Sebagian besar kebijakan diwujudkan dan diaplikasikan dalam bentukpelayanan sosial yang berupa bantuan barang, tunjangan uang, perluasan kesempatan, perlindungan sosial, dan bimbingan sosial (konseling, advokasi, pendampingan).

3. Sistem perpajakan: Dikenal sebagai kesejahteraan fiskal. Selain sebagai sumber utama pendanaan kebijakan sosial, pajak juga sekaligus merupakan instrumen kebijakan yang bertujuan langsung mencapai distribusi pendapatan yang adil. 
Kebijakan sosial seringkali

melibatkan program-program bantuan yang sulit diraba atau dilihat secara kasat mata (intangible aids). Masyarakat luas kadangkadang sulit mengenali kebijakan sosial dan membedakannya dengan kebijakan publik lainnya. Secara umum, kebijakan publik lebih luas daripada kebijakan sosial. Kebijakan transportasi, jalan raya, air bersih, pertahanan dan keamanan merupakan beberapa contoh kebijakan publik. Sedangkan kebijakan mengenai jaminan sosial, seperti bantuan sosial dan asuransi sosial yang umumnya diberikan bagi kelompok miskin atau rentan, adalah contoh kebijakan sosial.

Setiap negara memiliki perbedaan dalam mengkategorikan kebijakan publik dan kebijakan sosial. Di Inggris misalnya, kebijakan mengenai air bersih termasuk pada kebijakan sosial. Di China, kebijakan sosial mencakup pemberian makanan dan pakaian kepada masyarakat yang kurang mampu. Sedangkan di Belanda, kegiatan-kegiatan kebudayaan (cultural activities) merupakan bagian penting dari kebijakan social.

Kebijakan sosial sejatinya merupakan kebijakan kesejahteraan (welfare policy), yakni kebijakan pemerintah yang secara khusus melibatkan program-program pelayanan sosial bagi kelompok-kelompok kurang beruntung (disadvantegd groups), yakni

para

Pemerlu

Pelayanan

Kesejahteraan Sosial (PPKS), seperti keluarga miskin, anak telantar, pekerja anak, korban HIV/AIDS, penyalahguna Narkoba dan kelompok-kelompok rentan lainnya, baik secara ekonomi maupun psikososial.

\section{"GRIYA BACA" SEBAGAI LOKOMOTIF REVOLUSI SOSIAL BAGI ANAK JALANAN \\ Sejarah Berdirinya “Griya Baca” Malang}

Munculnya fenomena anak jalanan yang merupakan product dari industrialisasi maka perlu penanganan serius. Anak-anak jalanan perlu memperoleh perhatian dari semua jajaran masyarakat. Barangkali yang lebih perlu diperhatikan adalah anak-anak jalanan yang muncul dengan terpaksa, karena mereka ini pada hakikatnya kehilangan hak secara fisik, psikologis, ekonomi, dan lain-lain sehingga perlu perubahan nasib.

Dalam konteks Kota Malang fenomena anak jalanan tidak bisa dielakkan lagi. Anakanak jalanan ini sering beroperasi di pusatpusat keramaian seperti di seputar alun-alun, pasar besar, perempatan-perempatan lampu merah, dll.

Anak-anak jalanan yang sering beroperasi di kawasan Jagalan, alun-alun dan sekitarnya sangat perlu mendapatkan pembinaan secara intensif. Berdasarkan 
realitas yang ada, mayoritas dari mereka tidak pernah mengenyam pendidikan di bangku sekolah, mereka lebih banyak menghabiskan waktu dengan mengamen dan mengemis. Adapun unsur eksploitasi yang tinggi dari orang tua memaksa mereka untuk mencari nafkah.

Berangkat dari rasa empati dan kepedulian yang tinggi, layaknya anak-anak seusia mereka, sepatutnya anak-anak jalanan itu mendapatkan perlakuan dan pembinaan yang layak. "Griya Baca", hadir di tengahtengah mereka untuk berbagi. "Griya Baca" adalah suatu Lembaga Pemberdayaan Anak Jalanan di Kota Malang dengan akte notaris Faisal A. Weber., SH No : 11 tanggal 9 Februari 2007. Griya Baca didirikan pada tanggal 08 Oktober 2006 oleh aktivis mahasiswa yang peduli sosial di Kota Malang, berdedikasi kepada pembinaan moral anak jalanan dalam upaya mempercepat terwujudnya lingkungan bebas anak jalanan serta mencetak generasi bangsa memiliki moralitas tinggi.

Sampai saat ini jangkauan "Griya Baca" hanya berpusat pada alun-alun Kota Malang tetapi memiliki adik-adik binaan dari berbagai daerah seperti Jagalan, Muharto, dan Sukun. Lembaga ini memiliki prioritas dalam pengembangan life-skill, penguatan kualitas sikap mental danpengenalan kharakter wirausaha pada anak jalanan, pengembangan religiusitas anak jalanan, serta pembelajaran wacana sosial pada masyarakat tentang keshalihan sosial. "Griya Baca" sebagai lembaga pemberdayaan anak jalanan bersifat sosial independen, berdiri pada 2006 dan telah memilikiakte Notarissejak tahun 2007.

\section{Konsep Rumah Singgah "Griya Baca”}

Rumah singgah

sebagai tempat

perlindungan dari berbagai bentuk kekerasan yang kerap menimpa anak jalanan dari kekerasan dan prilaku penyimpangan seksual ataupun berbagai bentuk kekerasan lainnya, sebagai tempat rehabilitasi yaitu mengembalikan dan menanamkan fungsi sosial anak, dan sebagai akses terhadap pelayanan, yaitu sebagai persinggahan sementara anak jalanan dan sekaligus akses kepada berbagai pelayanan sosial seperti pendidikan, kesehatan.

Dalam operasionalnya rumah singgah mempunyai prinsip-prinsip yang sesuai dengan karakteristik pribadi anak jalanan.dan prinsip-prinsip rumah singah adalah Anak boleh keluar masuk (semi institusional), pusat informasi dan pusat kegiatan, terbuka 24 jam, hubungan bersifat kekeluargaan (informal), bermain dan belajar, tempat persinggahan dari situasi jalanan kesituasi lain yang dipilih dan terbaik untuk anak,serta belajar bermasyarakat. 
Tahapan pelayanan rumah singgah (shelter), pelayanan rumah singgah terbagi menjadi beberapa tahap berikut ini:

a. Tahap I: Penjangkauan

1) Secara intensif berlangsung pada tiga bulan pertama dan selanjutnya sesuai kebutuhan dan dapat menggunakan anak-anak jalanan lainnya;

2) Para petugas turun ke jalanan/kantong sasaran, bertemu dan berkenalan dengan anak jalanan;

3) Membuat pemetaan wilayah dan gambarkan keadaan anak jalanan;

4) Mengidentifikasi mereka secara kelompok seperti jenis kegiatan, asal daerah, kebiasaan dijalanan, dll;

5) Membentuk kelompok-kelompok, memilih ketuanya dan anggota dengan jelas;

6) Mensosialisasikan manfaat rumah singgah;

7) Menambahkan kepercayaan kepada pekerja sosial.

b. Tahap II: Pengkajian Permasalahan Anak Binaan

1) Induksi peranan anak jalanan di rumah singgah;

2) Mengisi file anak;

3) Mendiskusikan permasalahan anak;
4) Mambahas perkembangan kemajuan anak sesuai perubahan-perubahan yang terjadi pada anak.

c. Tahap III: Persiapan Pemberdayaan

1) Membuat rumah singgah sebagai suatu keluarga yang terbuka dan mau mendengar nasehat;

2) Membuat peraturan yang menyenangkan dan tidak memaksa anak;

3) Memberikan bimbingan sosial baik kasus maupun perilaku sehari-hari dengan cara dan metode yang menyenangkan;

4) Membuat jadwal pemeriksaan kesehatan setiap bulan;

5) Mengadakan kegiatan-kegiatan yang menyenangkan anak seperti permainan, olahraga, kesenian, dll;

6) Membagi penanganan anak jalanan oleh pekerja sosial. File untuk itu dapat dimintakan kepada petugas administrasi;

7) Membuat persiapan-persiapan pada diri anak terhadap kegiatannya.

d. Tahap IV: Rujukan Pemberdayaan

1) Mengidentifikasi anak secara satu persatu berdasarkan kebutuhan pelayanan; 
2) Menghubungi sumber-sumber yang diperlukan dan mendorong anak mendayagunakannya;

3) Menyiapkan anak memperoleh pelayanan tersebut;

4) Membuat kesepakatan dengan sistem sumber;

5) Mengantar anak memperoleh pelayanan;

6) Mendorong anak bertanggung jawab untuk melakukan kegiatan dan menerima pelayanan tersebut;

7) Memantau kemajuan anak selama memperoleh pelayanan dan membantu mengatasi kesulitan yang dihadapi.

e. Tahap V: Pengakhiran (Terminasi)

Tahap pengakhiran berarti anak selesai menerima pelayanan. Ada beberapa keadaan akhir pada fase ini, yakni:

1) Mandiri/ produktif/ alih kerja;

2) Anak kembali kepada keluarganya, panti atau lembaga pengganti;

3) Anak masih di jalanan;

4) Masuk boarding house;

5) Anak masih dijalanan, namun mendapat pekerjaan yang lebih baik;

6) Peningkatan pendapatan bagi orang tuanya.
"GRIYA BACA" SEBAGAI TRANSFORMASI KEHIDUPAN SOSIAL ANAK JALANAN

Anak jalanan dengan setumpuk permsalahannya menjadikannya sebgai permsaalahan sosial yang harus segera ditngani oleh negara. Kehadiran "griya Baca" merupakan inisiatif social masyarakat dengan kearifan local yang dimiliki. Dengan demikian penyelenggaraan pembinaan anak-anak jalanan yang diagendakan oleh "Griya Baca" terdapat beberapa instrument kegiatan yakni:

1. Penjangkauan dan pendampingan di jalanan; yang meliputi kegiatan-kegiatan Kunjungan lapangan dan perkenalan, Pemeliharaan hubungan dengan anak, dan Pembentukan kelompok di jalanan.

2. Pengkajian Masalah, meliputi:Pengisian file profil anak, Pengisian file monitoring perkembangan anak, dan Pembahasan kasus.

3. Resosialisasi, meliputi:Pengenalan peranan anggota rumah singgah, Kegiatan keagamaan, Pengajaran dan diskusi tentang norma social, Permainan, pertunjukan seni dan olahraga, Membaca buku, majalah dan menonton televise, Bimbingan sosial perilaku sehari-hari, Bimbingan sosial kasus, Pemeliharaan kesehatan, Penyatuan kembali dengan keluarga, Surat-menyurat dan kunjungan rumah kepada orang tua anak jalanan, dan 
Pertemuan dengan warga sekitar rumah singgah secara rutin maupun kegiatan bersana.

4. Rujukan Pemberdayaan untuk Anak Jalanan;

a. Pendidikan melalui sekolah-sekolah seperti beasiswa, alat sekolah, bimbingan belajar, kejar paket $\mathrm{A}$ dan $\mathrm{B}$, ujian persamaan;

b. Pelatihan anak jalanan untuk membekali anak berbagai hal dijalanan dan mendidiknya mampu mengatasi persoalan dan ancaman dijalanan;

c. Pelatihan-pelatihan untuk tingkatan remaja;

d. Pelayanan keterampilan kerja melalui lembaga pelatihan keterampilan seperti perbekalan menjahit, sablon, mengemudi, elektro dan lainnya yang disesuaikan keadaan wilayah;

e. Bantuan modal dan bimbingan usaha bagi anak baik di daerah asal maupun di kota secara perorangan atau berkelompok (KUBE);

f. Membantu anak menemukan pekerjaan lain. Para pekerja sosial berhubungan dengan berbagi sumber dan membuka kesempatan kepada anak untuk memperoleh pekerjaan.

5. Pemberdayaan untuk Orang Tua Anak Jalanan, meliputi: a. Bimbingan dan penyuluhan melalui kunjungan rumah, suratmenyurat, mengundang mereka datang atau pada saat mereka datang kerumah singgah. Kegiatan ini dilakukan perorangan atau berkelompok. Materi yang diberikan mengenai pengasuhan anak, nilai anak, cara mengatasi masalah anak, dan lain sebagainya;

b. Pemberian modal dan bimbingan usaha;

6. Terminasi (Pengakhiran Pelayanan)

Terminasi dilakukan untuk mengakhiri proses penanganan anak jalanan. Setelah dapat di normalisasi di rumah singgah. Palayanan lanjutan untuk anak-anak sesudah terminasi adalah 1). Berkenalan dengan orang tua anak; 2). Mengidentifikasikan mereka; 3). Memantau anak-anak yang sudah pulang; 4). Memberikan modal usaha kepada anak dan orang tua jika diperlukan; 5). Pemantauan terhadap Anak yang masih mengikuti kursus keterampilan, Anak yang bersekolah, Anak yang alih kerja, Anak yang melakukan usaha, Orang tua yang telah memperoleh bantuan modal, dan Rujukan ke panti-panti sosial.

Dengan adanya konsep rumah singgah diatas rumah singgah "Griya Baca" 
menampung Jumlah anak jalanan sampai dibawah ini: saat ini mencapai 75 anak seperti dalam table

Tabel I Jumlah Anak Jalanan di Griya Baca Malang

\begin{tabular}{cll}
\hline No. & Jenis Kelamin & Keterangan \\
\hline 1. & Laki-laki & 35 anak \\
2. & Perempuan & 40 anak \\
\hline \multicolumn{2}{c}{ Jumlah } & $\mathbf{7 5}$ anak \\
\hline \multicolumn{2}{c}{ Sumber: Dokumen Griya baca Malang, 2015}
\end{tabular}

Keseluruhan anak-anak jalanan yang menjadi warga binaan "Griya Baca" dibimbing secara formal dan informal dengan beragam kegiatan-kegiatan untuk menumbuhkembangkan semangat survivalitas anak binaan. Kegiatan-kegiatan yang disusun secara sistematis dan terukur setiap tahun untuk menjadikan anak-anak jalan berguna bagi bangsa dan negara.

Pembinaan rutin, kegiatan ini dilaksanakan dua kali dalam seminggu pada hari Selasa dan Sabtu. Kegiatan diawali dengan berdoa bersama kemudian belajar mengaji, pendalaman mental dan spiritual serta terakhir dilanjutkan dengan pembinaan akademik.

Outbond Anak Jalanan, kegiatan ini bersifat insidental, biasanya dilaksanakan 3 kali dalam sebulan dan pada perayaan hari libur nasional atau pada saat menerima undangan dan bakti sosial dari donatur.
Studi Wisata, kegiatan ini biasa dilaksanakan pada saat libur sekolah. Kegiatan ini bertujuan untuk membuang kejenuhan anak jalanan yang setiap harinya bergelut dengan kehidupan yang keras. Selain itu kegiatan ini merupakan bentuk pengetahuan tambahan bagi anak jalanan tentang berbagai macam keterampilan yang ditawarkan oleh masingmasing tempat yang dikunjungi.

\section{Dunia kreasi Anak Jalanan,} kegiatan ini dilaksanakan pada saat ulang tahun Griya Baca. Dalam kegiatan tersebut di diisi dengan beragam perlombaan meliputi mewarnai, puisi, tari, musical jalanan, baca Al-Quran dan lain-lain.

\section{Ramadhan On The Street,} kegiatan ini tentunya dilaksanakan pada bulan ramadhan diantaranya Buka puasa bersama, shalat tarawih, pengajian, dan bakti sosial.

Latihan Tari, music, dan teaterdilaksanakan 1 minggu sekali 
sebagai wujud kecintaan anak jalanan terhadap budaya bangsa Indonesia. Sementara itu, latihan music dilaksanakan 1 minggu 2 kali yaitu hari selasa dan hari juma't sebagai upaya penyaluran minat dan bakat anak jalanan yang kebanyakan berprofesi sebagai pengamen. Sehingga diharapkan anak jalanan mampu berekspresi dan menuangkan ide-ide mereka melalui musik. Dan teater dilaksanakan 1 minggu sekali sebagai sarana bagi anak jalanan yang senang pada dunia seni peran.

Beasiswa, kegiatan ini diberikan oleh Dinas Sosial Propinsi Jatim sebagai upaya meringankan beban anak jalanan yang masih mengenyam bangku sekolah. Sehingga diharapkan mereka akan terus termotivasi dalam mengikuti kegiatan belajar mengajar di sekolah, dan juga termotivasi untuk bisa berprestasi baik di bidang akademik maupun non akademik.

Kunjungan ke rumah anak jalanan, kegiatan ini bersifat insidental, sebagai upaya monitoring perilaku anak jalan setelah mengikuti kegiatan pembinaan di Griya Baca. Tidak hanya itu, kunjungan tersebut juga bermaksud untuk lebih mengetahui keadaan keluarga anak binaan dan juga dalam rangka silaturahmi untuk lebih dekat dengan wali anak jalanan.
Pelatihan, program latihan ketrampilan ini adalah upaya Griya Baca untuk menyalurkan bakat dan minat anak jalanan terhadap berbagai macam keahlian diantaranya, Pembuatan tempe yang bekerja sama dengan kwarcab kota malang dan Aliansi Anak Bangsa (ANGKASA), kursus menjahit yang bekerjasama dengan Depnaker, kursus otomotif yang bekerjasama dengan Dinas sosial propinsi Jawa Timur, pembuatan handycraft yang diselenggarakan oleh jurusan akuntansi Universitas Brawijaya Malang, latihan menari yang bekerjasama dengan Jaringan Kemanusiaan Jawa Timur (JKJT), dan juga latihan musik yang juga dibina oleh Aliansi Anak Jalanan (ANGKASA).

Selain kegiatan-kegiatan tersebut, dari data lapangan, dimasa akan datang Griya Baca akan terus mengadakan berbagai program berbobot sebagai upaya pembinaan anak jalanan dalam rangka menyiapkan SDM yang berkualitas mengikuti program dan harapannya ke depan mereka menjadi generasi bangsa penerus bangsa yang memiliki moralitas tinggi meski sebagian dari mereka tidak sekolah.Sehingga SDM yang diharapkan tidak hanya matang dari sisi intelaktual juga matang secara moral dan spiritual. 
Dari program revolusi social anak kehidupan social masyarakat lainnya. jalanan yang dimotori oleh "Griya Baca" Dilihat dari perkembangannya, anak-anak menjadikan lembaga social seperti griya jalanan yang menjadi binaan griya baca baca tetap eksis dalam proses terus mengalami peningkatan sejak pembentukan jiwa-jiwa anak jalanan kreatif didirikan tahun 2010 seperti dalam table yang terstruktur sehingga bermakna bagi berikut:

Tabel 2

Perkembangan Penghuni Shelter Griya Baca

\begin{tabular}{ccc}
\hline No. & Tahun & $\begin{array}{c}\text { Jumlah Anak Jalanan di Griya } \\
\text { Baca }\end{array}$ \\
\hline 1. & 2010 & 65 \\
2. & 2011 & 67 \\
3. & 2012 & 70 \\
4. & 2013 & 72 \\
5. & 2014 & 74 \\
6. & 2015 & 75 \\
\hline \multicolumn{2}{l}{ Sumber. Data Sekretariat Griya Baca, 2015}
\end{tabular}

Keberadaan "griya baca" di Kota Malang ini dilihat dalam hasil yang diperoleh dari memberikan manfaat besar bagi kehidupan kegiatan rutin yang dicanangkan, seperti anak-anak jalanan yang menjadi peserta dalam table berikut:

binaan. Keberlanjutan peserta binaan dapat

Tabel 3

Perkembangan Alumni Penghuni Griya Baca

\begin{tabular}{|c|c|c|c|}
\hline No. & Tahun & $\begin{array}{l}\text { Jumlah } \\
\text { Alumni }\end{array}$ & Keberlanjutan \\
\hline 1. & 2011 & 3 & $\begin{array}{l}\text { Lanjut sekolah, dan sudah kerja } \\
\text { mandiri, }\end{array}$ \\
\hline 2. & 2012 & 4 & Sudah kerja mandiri usaha bengkel. \\
\hline 3. & 2013 & 4 & Lanjut sekolah dan kerja mandiri \\
\hline 4. & 2014 & 6 & Lanjut sekolah dan kerja mandiri \\
\hline 5. & 2015 & 8 & $\begin{array}{l}\text { Lanjut sekolah,jualan di warung } \\
\text { (kerja mandiri). }\end{array}$ \\
\hline
\end{tabular}

Sumber: Sekretariat Griya Baca, 2015 


\section{KESIMPULAN}

Rumah Singgah "Griya Baca", juga merupakan sebuah bentuk pelaksanaan proses manajemen yang dilakukan oleh sebuah badan non profit. Dalam kaitannya dengan pemahaman istilah non profit, manajemen yang dilakukan oleh "Griya Baca" lebih kepada pemanfaatan Rumah Singgah sebagai tempat pembinaan anak jalanan.

Proses perencanaan program di "Griya Baca" terlaksana atas dasar pertimbangan akan berbagai kebutuhan dari para Anak Jalanan yang menjadi anggota dari Rumah Singgah. Hal ini menegaskan bahwa segala perencanaan strategis terkait penentuan kegiatan dan program selain program rutin, lebih dipengaruhi oleh faktor kondisional dan kebutuhan terkini dari para anak jalanan. Sehingga dengan demikian program dan kegiatan yang terlaksana lebih dominan merupakan program dan kegiatan rutin yang memang sudah menjadi program dan kegiatan yang secara teratur dilaksanakan pada waktu tertentu.

Pengorganisasian "Griya Baca" memiliki struktur kepengurusan yang jelas dan teratur secara formal. Dari struktur kepengurusan yang ada, telah terbagi jelas berbagai tugas pokok dan fungsi dari berbagai macam bagian kepengurusan.Namun, dalam pelaksanaan tugas dan kewajiban masingmasing bagian dari kepengurusan tersebut, tidak terikat dengan berbagai sanksi dan beban tertentu. Tidak adanya ikatan dan sanksi tersebut menyebabkan kinerja dari para anggota pengurus tersebut lebih ditekankan kepada kesadaran bukan karena paksaan.

Dalam pelaksanaan (Actuating), kegiatan dan program yang diagendakan, "Griya Baca" menekankan kepada kondisi kekinian. Hal ini berarti bahwa segala program dan kegiatan selain program dan kegiatan rutin biasanya dilaksanakan dengan melihat dan membaca kondusif tidaknya situasi untuk kemudian dilaksanakan kegiatan, atau bahkan melihat dibutuhkan atau tidaknya kegiatan tersebut pada waktu tertentu oleh para anak jalanan.

Sementara itu, system pengawasan (Controlling), lebih menekankan kepada pengawasan dengan pendekatan personal kepada para pengurus. Hal ini dilakukan mengingat tidak adanya ikatan secara insentif dengan para anggota pengurus, sehingga menyebabkan berbagai pengawasan kepada anggota pengurus lebih secara personal.Berbagai tindakan peringatan dan sanksi tidak diberlakukan karena memang tidak didukung oleh ikatan finansial dalam bentuk insentif. Secara lebih jauh juga penekankan kepada setiap upaya pengawasan terhadap kinerja yang dilakukan pengurus lebih kepada peningkatan kesadaran yang kemudian dibahasakan oleh ketua lembaga sebagai "panggilan hati". 
Secara umum Rumah Singgah "Griya Baca" mempunyai rencana program yang sudah terkonsep dalam visi misi dan program rutin tahunan. Namun dalam pelaksanaanya terdapat beberapa program yang terlaksanakan dan juga tidak terlaksanakan.Hal ini dikarenakan oleh kurang adanya kerjasama terkait program yang telah direncanakan seperti program seni teater dan kurang adanya pemateri sehingga program ini tidak terlaksana dan terealisasi.

\section{DAFTAR PUSTAKA}

Departemen sosial Republik Indonesia (2004) Standar pelayanan Anak Jalanan melalui Rumah Singgah, Departemen sosial Republik Indonesia, Jakarta.

Fahrudin, Adi, 2014, Pengantar kesejahteraan sosial, Refika Aditama, Bandung

Handoko, Hani, 2009, Manajemen, BPFE YOGYAKARTA, Yogyakarta.

Suharto, Edi, 2008, Kebijakan sosial sebagai kebijakan public, Alfabeta, Bandung

-----------, 2009, Membangun masyarakat memberdayakan rakyat, Reflika Aditama Bandung.

Cannon, Lisa, 2004, Menjadi ORNOP Mandiri , Yayasan Obor Indonesia,Jakarta.

Achmad Arief. "Pemberdayaan Anak jalanan",dalam http://www.Anak jalanan/artikel pendidikan Network,htm, Tanggal Akses, 9 september 2015.
http://digilib.uinsuka.ac.id.Penyelenggaraan pembinaan anak jalanan melalui Rumah singgah, Diakses 10 september 2015.

http://rumagsinggah-ku blogspot.co.id/ Standar pelayanan sosial Anak Jalanan Melalui Rumah singgah. Artikel. Diakses 10 september 2015.

Regulasi perundang- undangan.

Undang-Undang Nomor 23 Tahun 2002 tentang Perlindungan Anak (C 9). Bandung, Citra Aditya Bakti

Kebijakan Wali Kota Malang Nomor 88 Tahun 2011 Tentang Pemberdayaan Kesejahtraan Masalah Sosial. 


\title{
PETUNJUK BAGI PENULIS TERBITAN BERKALA ILMIAH \\ P U B L I S I A \\ Jurnal IImu Administrasi Publik
}

\begin{abstract}
Naskah diketik spasi ganda pada kertas kuarto sepanjang maksimum 20 halaman dan diserahkan dalam bentuk cetak (print out) computer sebanyak 2 eksemplar beserta soft file didalam disk berbentuk document (Microsoft Word) atau dikirim melalui alamat email: publisia.jopad@unmer.ac.id
\end{abstract}

Artikel yang dimuat meliputi kajian dan aplikasi teori, hasil penelitian, gagasan konseptual, tinjauan pustaka, resensi buku baru, bibliografi, dan tulisan praktis berkaitan dengan ilmu sosial, terutama dalam lingkup kajian ilmu administrasi Negara.

Artikel ditulis dalam bahasa Indonesia atau Bahasa Inggris dengan format esai, disertai judul subbab (heading) masing-masing bagian, kecuali bagian pendahuluan yang disajikan tanpa judul subbab. Peringkat judul subbab dinyatakan dengan jenis huruf yang berbeda (semua judul subbab dicetak tebal atau miring), dan tidak menggunakan angka nomor subbab:

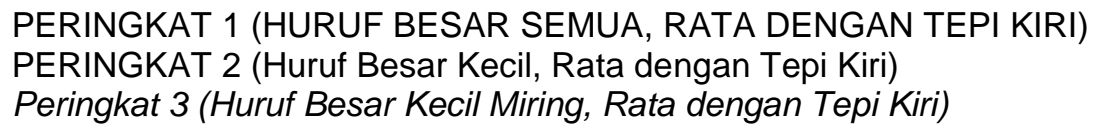

Sistematika artikel setara hasil penelitian: judul (diusahakan cukup impformatif dan tidak terlalu panjang. Judul yang terlalu panjang harus dipecah menjadi judul utama dan anak judul); nama penulis (tanpa gelar akademik); abstrak/intisari (maksimum 250 kata dengan disertai 3-5 istilah kunci (key word); pendahuluan (tanpa subjudul) yang berisi latar belakang dan tujuan atau ruang lingkup tulisan; bahasan utama (dibagi kedalam subjudul-subjudul); daftar rujukan (berisi pustaka yang dirujuk).

Sistematika artikel hasil penelitian: judul (diusahakan cukup impformatif dan tidak terlalu panjang. Judul yang terlalu panjang harus dipecah menjadi judul utama dan anak judul); nama penulis (tanpa gelar akademik); abstrak/intisari (maksimum 250 kata dengan disertai 3-5 istilah kunci (key word); pendahuluan (tanpa subjudul) yang berisi latar belakang, sedikit tinjauan pustaka, dan tujuan penelitian; metode; hasil; pembahasan; simpulan dan saran; daftar rujukan (berisi pustaka yang dirujuk).

Sistematika penulisan rujukan/daftar pustaka: rujukan/daftar pustaka ditulis dalam abjad secara alfabetis dan kronologis dengan ketentuan sebagai berikut:

a. Untuk buku: nama pengarang, tahun terbit, judul, edisi, penerbit, tempat terbit.

Contoh: Hicman, G.R. dan Lee, D,S., 2001, Managing humanresources in the public sector: a shared responsibility, Harcourt College Publisher, Fort Worth.

b. Untuk karangan dalam buku: nama pengarang, tahun, judul karangan, nama editor: judul buku, nama penerbit, tempat terbit, halaman permulaan dan akhir karangan.

Contoh: Mohanty, P.K., 1999, "Municipal decentralization and governance: autonomy, accountability and participation", dalam S.N. Jan and P.C. Mathur (eds): Decentralization and politics, Sage Publication, New Delhi, pp. 212-236

c. Untuk karangan dalam jurnal/majalah: nama pengarang, tahun, judul karangan, nama jurnal/majalah, volume/jilid, (nomor), halaman permulaan dan halaman akhir karangan.

Contoh: Sadhana, Kridawati, 2005, "Implementasi kebijakan dinas kesehatan dalam memberikan pelayanan pada masyarakat miskin", PUBLISIA, 9 (3): 156-171.

d. Untuk karangan dalam pertemuan: nama pengarang, tahun, judul karangan, nama pertemuan, waktu, tempat pertemuan.

Contoh: Utomo, Warsito, 2000, "Otonomi dan pengembangan lembaga di daerah", makalah disampaikan dalam Seminar Nasional Profesional Birokrasi dan Peningkatan Kinerja pelayanan Publik, 29 April 2000, Jurusan Administrasi Negara, FISIPOL UGM, Yogyakarta.

\section{Ketentuan lain:}

- Pemeriksaan dan penyuntingan cetak-coba dilakukan oleh penyunting dan/atau dengan melibatkan penulis. Artikel yang sudah dimuat dalam bentuk cetak-coba tidak dapat ditarik kembali oleh penulis.

- Penulis yang artikelnya dimuat wajib memberi kontribusi biaya cetak sebesar Rp. 250.000,- (Dua Ratus Lima Puluh Ribu Rupiah)*. 


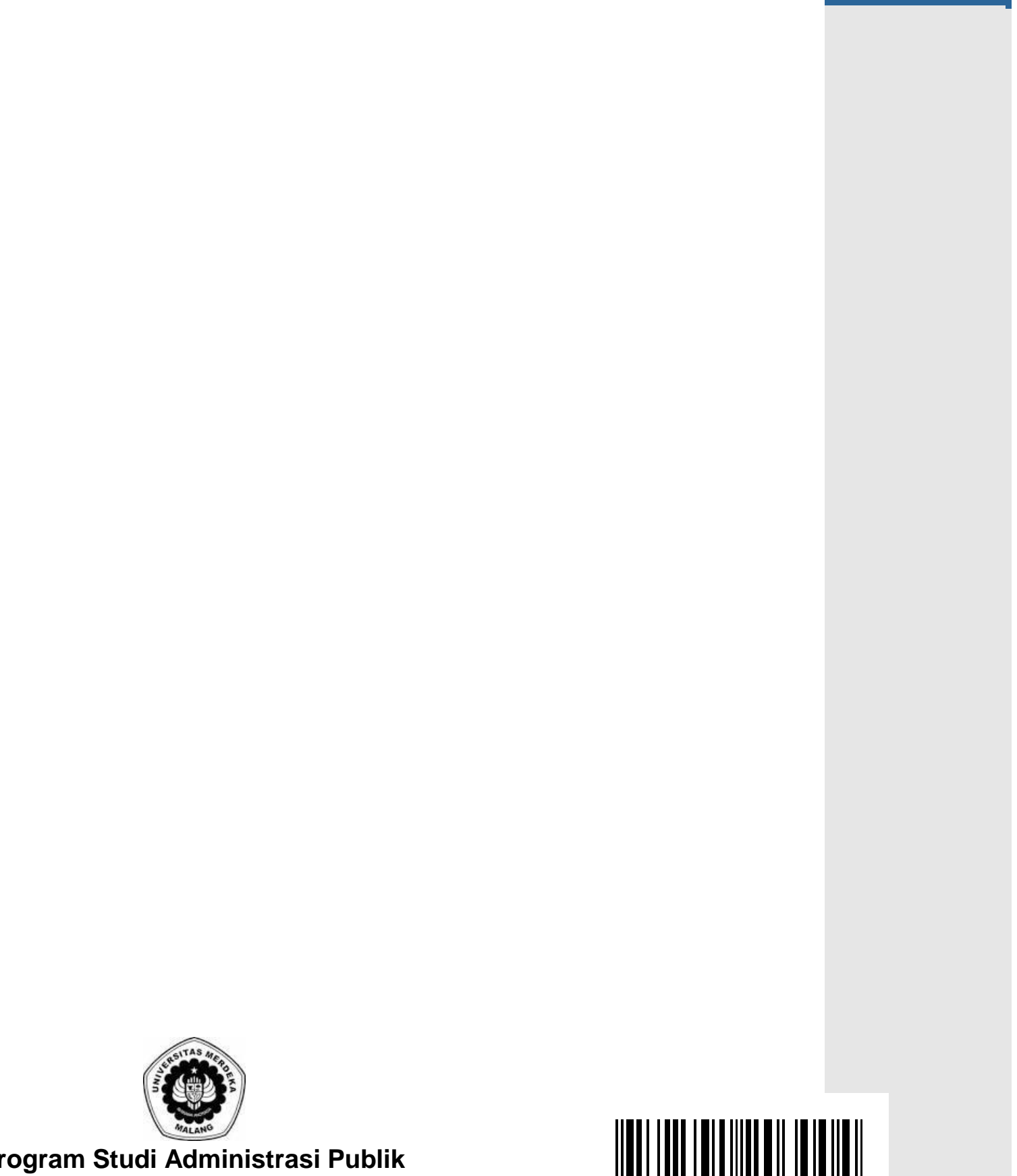

Program Studi Administrasi Publik FAKULTAS ILMU SOSIAL DAN ILMU POLITIK UNIVERSITAS MERDEKA MALANG

Jl. Terusan Raya Dieng no. 62-64 Kota Malang 65146

Telp. 0341-568395 psw. 873, Fax. 0341-580537 